\title{
City of Fear: Reimagining Buenos Aires in Contemporary Argentine Cinema
}

\author{
CATHERINE LEEN
}

National University of Ireland, Maynooth, Ireland

\begin{abstract}
Argentine cinema has experienced a rebirth since the late 1990s, despite the country's economic crisis. Buenos Aires, long a key setting for the nation's films, has not escaped the negative impact of the crisis, yet filmmaking in the capital has thrived. This article explores the radically different presentation of the city since the first explosion of film in Argentina after the end of the military dictatorship of 1976-1983. It takes Luis Puenzo's controversial La historia oficial as a starting point for a reflection on the current presentation of Buenos Aires as a city plagued by fear in productions from the late 1990s to the early twentyfirst century.
\end{abstract}

Keywords: Buenos Aires, city, crisis, desaparecidos, fear, military dictatorship.

Recent writing on Argentine cinema abounds with praise for the vitality of independent film in a country hard hit by economic recession. Paul Julian Smith, while acknowledging the continuing difficulties resulting from the recent economic crisis, notes that 'Argentina has an enviably healthy film culture dedicated to exploring the tragedies and ironies of national life' (Smith, 2004: 11). Pablo Suárez comments that 'the latest crop of so-called New Argentine cinema continues to break fresh ground' (Suárez, 2003: 11), while Dennis West reports that the films screened at the third Buenos Aires International Festival of Independent Cinema 'suggest that the nation's cinema will continue to boom' (West, 2001: 51). Given the proliferation of such glowing accounts, it was striking to find a report on the contemporary film scene that was less than laudatory. Guillermo de Carli finds that: 'The common element in many recent productions ... is this look which wants to be cold - or cool - about the squalid, which in the end is empty.' He concludes that 'there is no revelation, no images of movement, no visions of the future. There is what there is' (de Carli, 2003: 39-40).

What this account of contemporary Argentine film fails to grasp is that it is precisely the look of the films and their presentation of a radically different image of Buenos Aires that conveys their meaning. The socio-political critique in these films is often implicit, but it is strongly linked to its resolutely unglamorous and even threatening 
images of the city. As Karen Lury points out in her analysis of cinematic portrayals of the city:

An expanding body of literature ... uses historical and critical material related to the 'city' and discusses the way in which certain films have represented the modern or post-modern city. Furthermore, in relation to early cinemas, for example, such work has also attempted to understand the representation of the city by cinema as a fundamental part of the construction of actual cities themselves, and the lived experience of individuals who inhabit these particular places. (Mazierska and Rascarloi, 2003: 1)

This view is echoed by James Donald, who notes in Imagining the Modern City that:

The imagined landscape of the city has become, inescapably, a cinematic landscape. But the city in cinema does not operate just as a backdrop. Nor is the representation of the city really the issue ... film presents urban space as itself representational, as simultaneously sensory and symbolic. It thus provides a paradigm for understanding how and why we imagine the real-imagined space of the city. (Donald, 1999: 68)

The recent films that have been categorised as part of the 'New Argentine Cinema' share a tendency to expose the harsh realities that lie beneath the image of Buenos Aires as a modern, sophisticated city. The reasons for this change in the portrayal of the city are, of course, a reflection of the economic crisis that has rocked the country since the 1990s and that has attracted the interest of the international media, as Ángel Jozami notes in his compelling study Argentina, La destrucción de una nación:

Este renovado interés por la cuestión se observa en un sinnúmero de artículos periodísticos y en algunos pocos ensayos de corte sociológico y psicológico que se han publicado en la Argentina en los últimos años y, especialmente, en los meses de agonía final de la convertibilidad y en los días y semanas que siguieron al derrocamiento del gobierno de Fernando de la Rúa. Lo mismo, aunque limitado al plano puramente informativo, puede decirse del profuso uso de tinta, papel y films que se ha hecho en todo el mundo para dar a conocer a los principales aspectos de la situación. La magnitud del derrumbe explica este interés por el tema. (Jozami, 2003: $13-14)^{1}$

1 'This renewed interest in the question is notable in countless journalistic articles and a few sociological and psychological essays that have been published in Argentina in the last few years, especially in the dying months of peso-dollar parity and in the days and weeks that followed the downfall of Fernando de la Rúa's government. This interest, even in a purely informative sense, speaks of the widespread use of ink, paper and film worldwide to explain the principal elements of the situation. The magnitude of the catastrophe explains the interest in it.' (This and all subsequent translations are my own.) 
Jozami catalogues the events that followed the economic collapse of 2001, most obviously street protests, the looting of supermarkets and the erosion of the middle class (Jozami, 2003: 19-50). More recently, the continuing economic downturn and consequent social unrest led Alicia Entel to undertake a study of the fear she observed among the capital's residents. After conducting numerous interviews with inhabitants of Buenos Aires about their anxieties over the present climate, she lists their fears in the following order: fear of being robbed and of street crime, fear of delinquency in general, fear of losing one's job or not getting a first job, fear of the inhabitants of other neighbourhoods or cities, fear of the police, fear of drug dealers, fear of repression, fear of a lack of future prospects, and fear that people will forget the crimes of the dictatorship (Entel, 2007: 49-50). One respondent to the interviews suggests, poignantly, that the previous fear of the military dictatorship has been replaced by a fear of social exclusion as a result of straitened economic circumstances:

La gente le tiene miedo a la desaparición social y física que genera el desempleo, porque los desaparecidos de antes son ahora los que se quedan sin trabajo, desaparecen del circuito productivo, como padre y madre ya no podés abastecer a tu familia, te carcome la autoestima ... te quedás impotente, y eso es bronca acumulada que no sé dónde va a salir. (Entel, 2007: 54$)^{2}$

Entel's findings are similar to those of a recent poll conducted by the Centro de Estudios de Opinión Pública. What has come to be referred to, with considerable understatement, as la inseguridad [insecurity] is the principal cause for concern in this study, with 59.2 per cent of respondents expressing fear over armed robbery, carjackings and other violent crimes (Braslavsky, 2007: 3). This assessment of the current environment is reflected in a number of contemporary films that deal either with crime and marginality or the lingering memory of the dictatorship.

The previously prevailing image of Buenos Aires as a singularly attractive, modern city is closely linked to the often-noted unique status of Argentina among Latin American nations. Argentina's indigenous community is small, and its population derives mainly from European immigration in the nineteenth century. Its culture is therefore intimately associated with that of Europe. This sense of a close connection with Europe is mirrored in descriptions of Buenos Aires in the nineteenth century: 'The wide boulevards and elegant town houses in Buenos Aires proclaimed that here was a city that aspired to be the Paris of the southern hemisphere, a metropolis positioned ambiguously on the periphery of the world' (Sarlo, 1993: 164). The city's reciprocal fascination with European culture is noted in Jorge Coscia's reflection that although the tango was originally perceived as a threat to national identity as it was imported, it was

2 'People are afraid of the social and physical disappearance that results from unemployment, because the unemployed have become the new desaparecidos, they disappear from the productive world, as parents they can no longer support their families, your self-esteem shrivels ... you become impotent and I don't know where this problem, which keeps getting worse, is going to lead.' 
accepted widely in Argentine society after 'su triunfo en los salones de París y el resto del mundo "civilizado" (Coscia, 2005: 29). ${ }^{3}$ This close connection between Buenos Aires and Paris has held its grasp on the public imagination to the extent that journalist Cindy Loose was inspired to go to the city in 2005 to see if, in fact, it measured up to its European counterpart, reporting approvingly that:

[During] my days and nights in Buenos Aires, I had to keep reminding myself that I was in South America. Walking wide boulevards lined with fine, European-style architecture, past chic restaurants and bistros where people linger over meals, you sometimes feel as if you are in Paris. (Loose, 2005: 1)

So persistent has this image of Buenos Aires proved to be that in the 1980s, when Argentine cinema began to attempt to represent the national trauma that resulted from the human rights abuses of the most recent military dictatorship, there seemed to be considerable reluctance to move away from this image of the city as the Paris of the south.

Luis Puenzo's 1985 La historia oficial, the first film to chronicle the plight of the disappeared, portrays the capital as a space of opulence and sophistication. Alicia, the protagonist of the film, is first introduced in the privileged space of the private school where she teaches. The action then moves to her luxurious apartment, replete with the trappings of the upper middle class: expensive furniture, paintings and a maid to deal with domestic chores. Outside her home, she dines in opulent restaurants with her husband and friends. Even after Alicia learns that her friend Ana, who has returned to Argentina after a lengthy absence, fled the country as a result of being detained and tortured by the military on suspicion of subversive activity, she distances herself from this uncomfortable reality. Ana's disclosure is made in the comfortable confines of Alicia's apartment and thus Alicia is able to isolate herself from it, showing Ana the door and retreating into her cocoon-like home.

Although the luxury seen in Alicia's home is a result of her husband Roberto's dubious business dealings and close links with the military and is therefore implicitly the object of the viewer's censure rather than a mitigating element of the mise-en-scène, outside the home Alicia moves through a beautiful, tranquil city. Despite the disturbing turn that the film takes after Ana's revelation, which leads Alicia to reluctantly face the possibility that her adopted child, Gaby, is the daughter of a desaparecida, the film continues to offer solace to the viewer by focusing on the elite areas of the city. One such example is the meeting between Alicia and Ana at Ana's workplace, a Christian Dior boutique, which connects the women to a sophisticated fashion culture associated with Europe and the city of Paris in particular.

Despite this romantic portrayal of the city, David William Foster finds fault with the contrast between the scenes of Alicia's world and the film's street scenes on the grounds that this disparity reinforces what he terms 'smug foreign attitudes about Latin American governments'. He argues that:

3 'Its triumph in the salons of Paris and the rest of the "civilized world".' 
Puenzo's film may revolve around a classy woman like Alicia and show her moving in some very elegant surroundings, but once she goes out into the street, the screen is filled with scenes of political repression that suggest it is the sole basis for the everyday lot of Argentines and other Latin Americans. (Foster, 1992: 50)

In fact, an examination of the only outdoors scene in the film where Alicia encounters anything other than peaceful, tree-lined boulevards involves her coming upon a protest by the Madres de la Plaza de Mayo. She is pictured as entirely removed from the march, as Cynthia Ramsey notes: 'She waits on the margin of the protest march at the Plaza de Mayo and shows no sign of joining the organised movement' (Ramsey, 1992: 164).

Furthermore, the protest, while in itself a reaction to political oppression, takes place without any intervention from the military, so that there are no scenes that actually depict the horrors that provoked the mothers' activism, nor are they seen being persecuted by the military for daring to oppose the dictatorship. Moreover, Alicia's evident bafflement as she watches the women and the insistence of the film overall that she was completely unaware of what was happening around her would suggest that what she encounters here is far from the everyday experience of the upper middle class, who are wealthy enough to inhabit a city all their own, a space of luxury symbolised by expensive restaurants and boutiques. Foster concedes that there is no explicit representation in the film of the violence used by the military (Foster, 1992: 51). Ultimately, La historia oficial remains an important but flawed first step in confronting the legacy of the military dictatorship. The worst excesses of the dictatorship are recounted, not dramatised, and thus remain on the periphery of this story of the political enlightenment of a privileged woman who benefited from the regime.

Gustavo Castagna finds Argentine films of the 1980s problematic because of their equivocal depiction of the contemporary social situation as a consequence of their need to appeal to a middle-class audience: 'el problema del cine político en Argentina no tiene relación con el cine militante sino con la instalación de un discurso de clase media' (Triquell, 1997: 60). ${ }^{4}$ By the 1990s, however, the deeply divided city that is hinted at in La historia oficial became the focus of numerous films that deal with crime and marginalisation. As Catalina Donoso Pinto points out, a new vision of the city is a key element of contemporary productions by young filmmakers: 'Se trata de nuevas lecturas de la gran urbe - Buenos Aires - que cuestionan el estereotipo culto y europeizado de la capital argentina' (Donoso Pinto, 2007: 12). ${ }^{5}$

Puenzo's presentation of Buenos Aires will now be compared to a number of more contemporary films: Adrián Caetano and Bruno Stagnaro's Pizza, birra, faso (1997), Adrián Caetano's Bolivia (2001), Pablo Trapero's El bonaerense (2002), Daniel Burak's Bar 'El Chino' (2003), Marco Bechis's Garage Olimpo (1999), Albertina Carri's Los

4 'The problem with Argentine political cinema is not its relation to militant cinema but its adherence to a middle-class discourse.'

5 'These films offer new readings of the big city - Buenos Aires - which question the cultured, Europeanised stereotype of the Argentine capital.' 
rubios (2003), Juan José Campanella's El hijo de la novia (2001) and Fabián Bielinsky’s Nueve reinas (2000).

\section{Crime, Cops and the Crisis}

The film that undeniably moved away from any half measures in the portrayal of urban squalor and violence in Buenos Aires is Pizza, birra, faso. This film depicts a group of youths - el Cordobés, Frula, Megabom and Pablo - who share a house and live on the proceeds of their criminal activities. The pressure put on el Cordobés to provide for his girlfriend Sandra, who is pregnant with the couple's first child, leads him to plan a major heist with disastrous results. Their seedy, decrepit house and its rundown surroundings underline the group's marginalisation and lack of opportunity and explain if not justify their recourse to desperate means in a bid to secure the finances needed to realise their dreams. As Eduardo Antin Quintín observes: 'La ciudad que la película describe es una ciudad sucia, nocturna, en la que se alternan la crudeza y la esperanza, pero no hay lugar para la retórica' (Quintín, 1997: 5). ${ }^{6}$

The plot unfolds in a city where some signs of progress or prosperity are evident, yet the protagonists are excluded from any improvement in living standards. The gang robs passengers in taxis on the way to the airport on two separate occasions. The gang themselves never enter the airport, however, as to do so would suggest they would have the opportunity of taking flights or even leaving Buenos Aires. The establishing shot, seen just before el Cordobés and Pablo climb into a taxi to rob a businessman, features a montage that amounts to a vertiginous image of a city on the verge of collapse: buses trundle past market stalls, a man preaches revolution through a megaphone while no one listens, another man in a wheelchair struggles to move through the streets, while a shot of a shanty town segues to clips of beggars and windscreen washers at intersections. The film's final scene, where a wounded Cordobés cannot escape to Uruguay with Sandra, underlines the way in which the gang's liminal existence in the city has ensnared them.

Although these petty thieves who dream of pulling off a major heist should inspire fear, Caetano's film is striking not only in its lack of moral judgement, but in the way in which he humanises his protagonists. Even more than the troubled love that is evident between the young couple, the friendship between el Cordobés and Pablo is touching and convincing. Although they are fleeing from the law, Pablo insists on helping the wounded Cordobés join Sandra towards the end of the film. Moreover, their most successful crime, when they rob the taxi driver who had previously been their boss, is so amateur that it is both hilarious and moving. Having attacked and incapacitated the driver, Pablo and el Cordobés force his passenger, a middle-aged woman, to drive, as they did not have the foresight to consider the fact that neither of them could. This lack of driving skills is a further indication of the pair's lack of mobility.

6 'The city that the film depicts is a dirty, nocturnal city where rawness and hope intermingle, but where there is no room for rhetoric.' 
The gang are essentially doomed by their circumstances. The heavily pregnant Sandra becomes so disillusioned with her situation that she prefers to live with her abusive father than stay with el Cordobés. Her parting shot is: 'Si querés que vuelva, buscá un laburo como la gente'. Although her insistence that her boyfriend get a job seems reasonable, given the number of people seen queuing for any job this goal is utterly out of reach. In a later scene, el Cordobés believes that his acquaintance Miguel refuses the gang admission to a disco he works at because having a job has gone to his head. With no prospects of work and little hope of success as career criminals, the youths are easy prey for the police who expend little effort in catching and eliminating them. Despite its grim subject matter, the film succeeds in communicating a sense of solidarity and even love between the friends, as Elisa Vidal comments:

\begin{abstract}
No hay traiciones en el grupo. La fidelidad gana. Sobre el final, Córdoba (sic), con una herida mortal, cumple con su promesa, ayudado por Pablo, y en ningún momento piensa en abandonarlo. (Vidal, 1999: 163-164) ${ }^{8}$
\end{abstract}

Sandra achieves the dream of starting a new life and through their child el Cordobés's dream is not entirely lost. The casual way in which the police call for an ambulance and a hearse for the dead gang members as the ferry moves off lends a far from sentimental note to this conclusion, however. The lives of these young men are expendable, their deaths an unremarkable event in a city stricken by crime.

In some ways, $E l$ bonaerense is the most disturbing recent portrayal of crime and fear in the city. The fact that the police ranked higher than drug dealers in Entel's list of fears becomes understandable in the context of this study of corruption, brutality and amorality in the city's police force. The story follows the fate of Zapa, a naïve locksmith who participates in a robbery in his small town but is saved from prison by his uncle, a former police chief who uses his contacts to get his nephew into the Buenos Aires police force. Even Zapa's first dealing with the force involves a falsification, as his age is adjusted downwards on his application from 32 to 28 so that he meets the force's requirements. The first real signs that the force is utterly corrupt come when Zapa watches other officers take bribes in the form of Christmas cakes from a man outside the station. Soon after, despite being on duty, the officers celebrate the arrival of Christmas Day by getting very drunk, firing their pistols in the air as fireworks explode in the sky above them. The station's inspector is replaced soon after by Gallo, who is to become Zapa's mentor. Gallo's speech to his officers on being appointed is a masterpiece of hypocrisy and cynicism:

Estamos para resolver los problemas de la comunidad porque somos parte de la comunidad. No puede haber oposición entre la institución policial y

7 'If you want me to come back, get a job like a normal person.'

8 'There is no betrayal in the group. Loyalty wins out. In the end, Córdoba [sic], who is mortally wounded, fulfils his promise helped by Pablo, and he never once thinks of abandoning him.' 
los ciudadanos comunes, honestos ¿no? Los problemas no se deben resolver ni con debilidad, señores, ni con gatillo fácil. ${ }^{9}$

Immediately after this, the hollowness of his speech on morality and ethics is made clear by his introduction of Zapa to an officer called Cáneva, who instructs him in collecting protection money from a range of businesses and from street prostitutes.

In the field, what is most notable about Zapa's performance is his evident terror. He acquits himself poorly in every situation that requires aggression and violence, and he mostly observes instead of acting. When he and Lanza come across a group of bedraggled, drunken youths fighting, Lanza quickly brings them under control, while Zapa is mocked by the two youths he waves his gun at, and fires helplessly into the air as they escape. In his next assignment, a shootout between the police on a bridge and a gang on the ground below them, he is so panic stricken that he has to be told to take his gun out, and he then fires blindly from the bridge. As Aguilar comments, this scene is one of the most ominous in terms of its portrayal of the city: 'La exterioridad es un hueco negro, confuso e impenetrable del que surgen la agresión y la brutalidad' (Aguilar, 2006: 127). ${ }^{10}$ After this, a shaken Zapa tells Gallo about his meeting with his former boss Polaco, who has come to Buenos Aires to involve him in a robbery. This robbery leads to Zapa's final contact with the city. Following Gallo's instructions, he robs a safe with Polaco but then holds him prisoner until the arrival of Gallo, who steals the money, kills Polaco and shoots Zapa in the leg to make the murder look like self-defence. After this, Zapa is promoted to Corporal and returns home.

Aguilar argues that the family-like refuge offered by the police force to its members makes a good man like Zapa corrupt. In fact, Zapa 'remains constant in his passivity' (Walters, 2003: 13). He is neither good nor bad but a cipher, a blank slate on whom Polaco or Gallo can project their wishes. The film is not interested in heroes or villains, as in the final analysis there is little to choose between Zapa's bosses except that Gallo has the power of an entire institution behind him. The city that gives the force its name is dark and menacing, and the winners in this space of fear and violence are those who have the most resources at their disposal, hence the accumulation of scenes featuring bribes and misappropriated funds, which Gallo openly uses to buy weapons in one scene. The film ends on a somewhat inconclusive note, as Zapa's transfer from Buenos Aires does not mean the end of his police career. He is free of both his masters, however, and takes refuge in the far less threatening space of his home in the countryside.

Caetano presented a different side of the hidden city in his 2001 film Bolivia, which is notable for its overwhelmingly negative view of the capital: 'The film stands out due to the desolate brutality and stark aesthetics (filmed in black and white) with which it

9 'We are here to solve the community's problems because we're part of the community. There must be no conflict between the institution of the police and ordinary honest citizens, OK? We should not solve problems either by being weak, men, or by being trigger happy.'

10 'The world outside is a black hole that is confusing and impenetrable and from which aggression and brutality explode.' 
depicts some of the least likeable features of the culture of Buenos Aires, notably its xenophobia' (Gundermann, 2005: 243). The story centres on Freddy, an immigrant from Bolivia, and on the café in a rundown area of the capital where he works. Freddy endures ceaseless racism from the café's regulars, who are themselves suffering the degradations brought by reduced economic circumstances. In what is something of a darkly comic running joke, he is forced to constantly point out that he is Bolivian, not Peruvian or Paraguayan, as the Argentine characters assume. Their lack of interest in his nationality suggests that, for them, he is just another immigrant, whose only significance is the threat that the cheap labour he represents will worsen their own circumstances. Rosa, Freddy's Paraguayan co-worker, attracts unwelcome attention of a different kind from her customers. Paradoxically, the café, itself an unattractive and rather oppressive space, functions as a refuge for Freddy and Rosa as Gustavo Noriega points out:

\begin{abstract}
Caetano realiza un catálogo de los pequeños robos y humillaciones cotidianas que sufren los más humildes y del efímero y quebrado espacio de refugio que disponen. Esos pequeños espacios de resistencia tienen su correlato en la parrilla en la relación entre Freddy y Rosa, la empleada paraguaya, relación llena, como toda la película, de pequeños y significativos detalles. (Noriega, 2002: 15) ${ }^{11}$
\end{abstract}

One such detail is seen here when they share their tips, an act of solidarity and even resistance to the violence and hostility represented by the city's native inhabitants. Ultimately, however, they are unable to protect themselves from the increasing hostility of the café's clients. Oso, who has turned to drink since being laid off, is particularly resentful of Freddy, whom he sees as undercutting him by accepting low wages and thus depriving him of any hope of re-entering the job market. Oso's growing anger finally explodes when he is denied a free choripan, a hot dog that although priced at only 1 peso is beyond his means. His racist invective against Freddy at this point culminates in murder when he drives past the café and in a blind rage shoots Freddy. Oso's crime is the manifestation of a fear of becoming part of an underclass that finds a scapegoat in the immigrant. Freddy, in turn, comes to a tragic end because of his lack of understanding of the depth of hatred his presence provoked and his consequent lack of fear for his life until it is too late.

Bar 'El Chino' is similar in structure to Los rubios, which will be discussed later, in its interweaving of documentary and fiction. The bar that gives the film its title is the subject of a documentary that the protagonist, filmmaker Jorge Costa, has abandoned. As Jorge celebrates his birthday at the bar with his friends, a chance encounter with a young filmmaker, Martina, leads to their collaboration on the film and to a love affair. As they journey separately to the bar, the camera pans through streets filled with

11 'Caetano catalogues the small daily thefts and humiliations that the most humble in society suffer, as well as the ephemeral and fragile refuges they inhabit. Those small spaces of resistance have their parallel in the relationship between Freddy and Rosa, the Paraguayan waitress, a relationship full of small, significant details, like the film as a whole.' 
symbols of poverty: a juggler busks at traffic lights, children search through rubbish for food and Jorge and his friends are targeted by windscreen washers.

Jorge and Martina shut themselves in Jorge's house, which is also his studio, working around the clock to finish a documentary about Spanish investment in Argentina's highways for Jorge's Spanish partner Jesús, so that they can have both the money and the time to finish their documentary on the bar. When Jorge goes to get breakfast, he comes back with the news that the city is in turmoil. A report that the couple watches on CNN shows crowds looting a supermarket; later, martial law is declared and the president's resignation is announced. Jorge and Martina open the door of the house and see hoards of people in the streets banging pots in the peaceful protests that became known as the cacerolazo.

There is a sharp and ironic contrast between the calm, complacent narrative of the Spanish video, which foresees a prosperous future for Argentina, and the scenes of supermarket lootings (Page, 2007: 61). What is also notable about the CNN footage is the direct, almost panicked proclamation by one looter - a father of four who has been unemployed for two years - in an interview, contrasting with the sentimental nature of the interviews with the 'El Chino' regulars that make up much of the film. These interviewees constantly return to the themes of nostalgia and community as a reason for living in Buenos Aires, and the space of the bar functions as one of stability and authenticity in a rapidly changing and hostile world.

The few scenes in the film that show the nation's rapid decline are seen at a distance, whether from the safety of Jorge's home or mediated through news reports. Although Martina does suffer directly as a consequence of the economic downturn and eventually moves to Spain to work with Jesús, Jorge, despite his complaints about not being paid for the video, seems able to live normally. The song that functions as a leitmotif throughout the film, 'Alma, corazón y vida' [Soul, heart and life], whose singer explains that because he has no fortune these three things are all he has to give, reflects the film's sentimental approach to the fallout of the crisis and its utter failure to engage with the fear and confusion that the majority of the population experienced.

\section{Fear and Dictatorship}

Recent films that deal with the spectre of the military dictatorship have, unlike La historia oficial, almost exclusively focused on the victims of the dictatorship. Many of these films, including Sol de noche (Ludin and Milstein, 2003) and Nietos (identidad y memoria) (Ávila, 2004), have chosen the documentary form to communicate this dark history. Marco Bechis's 1999 Garage Olimpo is something of an anomaly in that it is neither a documentary nor is it based on a true story. An important precursor for this film is $\mathrm{La}$ noche de los lápices (Olivera, 1986), which is set not in Buenos Aires but in La Plata and focuses on the true story of the detention and subsequent disappearance of all but one of a group of eight high school students who protested against an increase in the cost of student bus tickets. This film was the first to detail the torture and sexual abuse 
that political prisoners endured, abuses based on the testimony of the only surviving member of the group. It had such an impact that the date of their arrest, 16 September, has been declared Students' Day in Buenos Aires and other districts, and it is usually marked by the screening of the film (Jakubowicz and Radetich, 2006: 172-173).

Garage Olimpo can to some extent be read as a hard-hitting remake of La historia oficial. This film also features a plot about a mother's quest for the truth about her daughter, but in this case the mother is seeking a daughter, María, who is involved in anti-dictatorship political activism. Even at the film's outset, Diane, María's mother, is forced to take in tenants to keep her home, an indication that although she is clearly middle class, she does not have the wealth to protect herself from the dictatorship's excesses. One of her tenants is an introverted young man called Felix, who is in love with María. During a raid on the house by the military, Felix is shown to hoard dozens of pens, watches and lighters, all of which he has taken from people he tortures in the hellish underground detention centre that gives the film its name.

Even before this revelation about Felix, there are ominous portents. The establishing shot features a radio report - significantly relating to the Argentine air force accompanied by an aerial shot of the city that features a long sweeping overview of the Río de la Plata. The film is punctuated by such aerial shots of the city, which are either disturbing in their associations with military surveillance, or in their presentation of the virtually deserted metropolis whose citizens seem afraid to leave their homes.

María, whose work teaching adult literacy in the city's slums presents us with another unfamiliar view of Buenos Aires, that of its villas miseria [shanties], is taken to Garage Olimpo. Most of the rest of the film takes place in this bleak, lightless bunker where lingering scenes of torture are set and from which prisoners are taken, drugged but still alive, to be killed. It is the graphic nature of these scenes, which occupy much of the film, that lends it its force. Time and again María and other prisoners are seen naked and on the verge of death, while the inhuman treatment meted out by their torturers is detailed through a series of disturbing images. Even more chilling is the casual nature of the relationship between torturer and victim, with one guard asking María about her age and her studies and joking that if she drinks water after being electrocuted she will end up like fried chicken. The children of the desaparecidos are held in a separate cell in Garage Olimpo while their parents are tortured or taken to their deaths. Another disturbing element in the story is the relationship between María and Felix, who is both her torturer and her lover.

At the film's conclusion, the camera pans over the drugged passengers who are to be dropped out of a plane as it ascends. The final shot returns to the Río de la Plata, which frames the film. In Pizza, birra, faso, the river represents the possibility of a new start in Uruguay. In Garage Olimpo, the river is transformed into a murky grave. The titles at the conclusion of the film leave no doubt as to the horrors perpetrated by the regime, underlining the fact that none of the perpetrators was brought to justice.

Despite being a co-production between Argentina, Italy and France and therefore having many more resources than Pizza, birra, faso, Garage Olimpo did not achieve anything like the success of Puenzo's film. As César Maranghello observes, 'El fracaso rotundo en taquilla dejó la amarga lección de que, para que una propuesta artística sobre el horror del Proceso fuese aceptada, debía escamotear la verdad' (Maranghello, 
2005: 268). ${ }^{12}$ Notwithstanding its poor box-office performance, Garage Olimpo remains an extremely courageous film that has paved the way for more recent fictional films that also deal with the guerra sucia's darkest aspects, such as Caetano's 2006 film Buenos Aires 1977. Bechis based Garage Olimpo on his experience of being detained (Jakubowicz and Radetich, 2006: 187). He avoids autobiography, however, thus freeing himself to show horrifying images of torture that would be difficult to include in a documentary.

In contrast, other contemporary films about the dictatorship, such as Los rubios and Kamchatka (Piñeyro, 2002), take a much more personal approach to the subject. Kamchatka, the story of a young boy's last days with his parents before they disappear, is so elliptical that a viewer unfamiliar with the history of the dictatorship would be hard pressed to understand it, while Los rubios takes an experimental approach to its subject. The latter is the first to be made by a child of parents who disappeared under the regime, and its director explains that she chose to merge documentary, fiction and even animation in the film because she did not identify with previous films on the subject, which she felt concentrated on politics and history at the expense of communicating the sense of loss felt by the children of the disappeared (Page, 2005: 34).

Carri uses an actress to play herself, and her film is as much a film about the making of a film as a quest to find out what happened to her parents, Ana María Caruso and Roberto Carri. Carri's film both belongs to a wave of films that deal with the dictatorship and its legacy, and 'deconstructs that wave' (Gandsman, 2006: 254). The complex negation of memory in the film has been discussed at length by Joanna Page (2007), Gabriel Nouzeilles (2005), and others. A striking element of Los rubios that has been noted less is its treatment of fear. Karen Backstein points out that the first woman interviewed by the crew speaks to them through an open window and behind the railings that encircle her home. She adds that 'these interviews, more than anything else, powerfully convey the dictatorship's lingering effects, less through the speakers' reminiscences than through their nervousness and reluctance to appear on camera at all. Fear permeates everything' (Backstein, 2004: 50). This evident but undefined fear is transmitted to the crew as they are taken to a police station to explain why they are filming. Cameraman Santiago warns Carri not to give her real name, and she hides her copy of the key report on the disappeared, Nunca más. Moreover, Carri's sister Paula refuses to be interviewed, while her sister Andrea does participate in the interviews but seems reluctant to talk openly on camera. Lorena Cancela comments on the approach adopted by Carri and others as follows:

Lejos de esconderse en fórmulas narrativas ya probadas como La Historia Oficial (Luis Puenzo, 1985), una de las características de los nuevos largometrajes es que sus realizadores cuentan la historia desde adentro, desde el dolor. Ya sea que porque son hijos de desaparecidos, o porque

12 'Its utter failure at the box office left the bitter lesson that, if an artistic work about the dirty war is to succeed, it must skirt the truth.' 
han hecho suyo aquel trauma, los realizadores están allí, y los espectadores también. (Cancela, 2004: 13)

A final film about the dictatorship that also takes a novel and extremely personal approach to the subject is Dady Brieva and Gerardo Valina's comedy Más que un hombre (2007), which screened in Buenos Aires in October 2007. This film falls outside the remit of this article, as it is set outside the capital, but it is notable for its attempts to present the military persecution of political dissents in the context of a light-hearted story involving a gay dressmaker who gives refuge to a young activist. The film veers dangerously close to presenting the military as buffoons rather than merciless and indiscriminate assassins, but it is well-acted and undeniably entertaining, and certainly takes a novel approach to its subject.

\section{The City, Fear and Box Office Success}

Silvina Díaz includes Pizza, birra, faso, Garage Olimpo and Bolivia in her list of films that espouse the values of the New Latin American cinema of the 1960s, although she does not see the 1990s films as a movement per se. She adds that these 1990s filmmakers have abandoned the 1960s idea that cinema could be a tool for social transformation and that instead they concentrate on chronicling the political and social changes in Argentina since the time of the guerra sucia. Díaz praises 1960s Argentine filmmakers for showing a side of the nation completely absent from traditional cinema, but she notes that they fell into the trap of concentrating so much on socio-political messages that there was little scope to develop a personal style, unlike the films of the 1990s:

En los 90, en cambio, si bien la crítica social se acrecienta, al mismo tiempo se busca enfatizar las interpersonales, sin la pretension de retratar de un modo documental el contexto social. La crisis es un componente que resulta determinante en la vida de los protagonistas, no obstante aparece relegada a la condición de entorno, de escenario en el que tienen lugar las desventuras de los personajes, con lo cual la denuncia adquiere una fuerza inusitada y la crítica funciona de un modo más efectivo. (Díaz, 2005: 119$)^{14}$

13 'Far from taking refuge in tried and tested narrative formulas like La historia oficial (Luis Puenzo, 1985), one of the characteristics of the new features is that their directors tell the story from within, taking their pain as a starting point. Whether because they are the children of the disappeared, or because they have made the trauma their own, the filmmakers are there on the screen, and so is the audience.'

14 'In the 1990s, on the other hand, if social criticism increased, at the same time there was an attempt to emphasise interpersonal stories, without the pretension of portraying the social context in a documentary-like manner. The crisis is a decisive element in the lives of the protagonists, notwithstanding the fact that it is relegated to the status of background detail, of a setting in which the misadventures of the protagonists take place, with the result that the critique takes on an unprecedented force and functions more effectively.' 
Given this context, it is hardly surprising that these filmmakers have chosen an aesthetic and positioning that reject the replication of images of the middle-class spaces so strongly associated in the minds of many with memories of cronyism, corruption and state terror. It is less clear, however, to what extent the most commercially successful films of the recent boom, El hijo de la novia and Nueve reinas, represent a move away from the idealised portrayal of Buenos Aires. Unlike the films mentioned by Díaz, both were international co-productions with large budgets and high production values. Despite this similarity, these films are often considered by critics as diametrically opposed to each other. El hijo de la novia, short-listed for the Best Film in a Foreign Language Oscar in 2000, is generally dismissed as a sentimental, cliché-ridden commercial film, while Nueve reinas, despite being a slick production that was remade as the Hollywood film Criminal (Jacobs, 2004), is widely seen as continuing the tradition begun by low-budget, independent films such as Pizza, birra, faso and Bolivia.

El hijo de la novia is perhaps the film that compares most closely stylistically to La historia oficial. Eddie Cockrell notes approvingly that its 'tech work is glossy and solid, with Buenos Aires coming across once again as a sophisticated, picturesque urban metropolis' (Cockrell, 2001: 66). The film also shares the sentimental tone of La historia oficial and again revives the family melodrama genre in a story that follows the attempts of Rafael's father to arrange a church wedding with his wife, who suffers from Alzheimer's. What sets the film apart from La historia oficial, however, is the radical change in the portrayal of the middle class. Rafael, the protagonist of El hijo de la novia, is so stressed by keeping his family's restaurant afloat that he has a heart attack at the age of 42 and is forced to contemplate selling the business to an international company. The film also gives an intriguing insight into the move from a celebration of the foreign and international as a mark of the status of Buenos Aires as a global city towards a distinct unease regarding the encroaching forces of globalisation.

Rafael first meets a representative of the company that will eventually buy his family business near the start of the film. He leaves his beautiful apartment, with exposed brick walls, trendy furniture and a trophy girlfriend to move to the street, where a car roars by him as he complains to his bank on his mobile phone that funds he has lodged have not yet cleared. When the action moves to the restaurant, a warmly lit and tastefully furnished space, the façade of his prosperity is made clear by his exchange with his head chef, who complains that he cannot make proper tiramisu without mascarpone cheese, which Rafael refuses to buy because it is too expensive. In this scene, Rafael declines to sell on the grounds that Argentina is a country perpetually rocked by one crisis or another and that he will survive this one just as he has done before, despite the warnings of his prospective buyer Scialli that this new crisis is different. The fact that Rafael sees the restaurant opposite closing down when he goes out into the street once more is a clear indication that Scialli will be proved right and that he will be forced to sell.

The meeting in which he transfers the ownership of the restaurant to the Marchioli company takes place on the top floor of a huge skyscraper. Interestingly, Laura Podalsky's 
account of the architecture of 1960s Buenos Aires notes that skyscrapers represented both a physical and metaphorical elevation above the average city dweller:

In Buenos Aires, the high-rises offered a position from which to see society as a whole, a perspective impossible from the streets ... the constructions made available a vision of an integrated city-text for those who could pay for it. If readable, the city might be controllable and less threatening. (Podalsky, 1997: 7)

Far from affording Rafael a measure of control, however, his presence in this office is a reflection of his capitulation and inability to maintain control over the family business and his own life. He is first seen in long shot sitting in front of the huge glass wall that affords a panoramic view of the city. The camera moves quickly to a close-up shot from below so that he seems to float vertiginously over the city as a lawyer recites the terms of the contract that he then signs. After signing, his face is reflected upside down in the mirrored table, suggesting his anxiety and turmoil about the sale and its meaning for his family. Although these feelings of insecurity and guilt are ultimately resolved by the family's purchase of another restaurant, an act that assuages the destruction of family tradition by a global business, this sequence expresses a great deal of ambiguity about Argentina's place in a world economy. Thus, despite the general conservatism of the film, it does offer something of a challenge to the hegemony of globalisation. Maranghello notes that this seemingly frothy entertainment has some critical content: 'entre líneas, se permite unas pinceladas de testimonio social' (Maranghello, 2005: 262). ${ }^{15}$

Nueve reinas, like El hijo de la novia, adopts a Hollywood aesthetic both in its use of genre (it has routinely been lauded by US critics as a 'Latin Sting ${ }^{16}$ ) and its rather slick visual style. The extremely complex, twist-laden plot follows the adventures of con man Marcos, who at the outset of the film recruits the inexperienced fraudster Juan as his new partner. Despite his quick wit and appealing streetwise attitude, Mar$\cos$ is a despicable character, who has cheated his sister Valeria and his younger brother Federico out of the inheritance left to them by their grandparents. The pair are thus forced to work long hours in low-paying jobs in a glitzy, cosmopolitan hotel. This and many of the film's other locations, even the Esso station shop that is the setting for the establishing shot, suggest that the city has an international flavour and that many of its inhabitants enjoy lives of privilege and luxury. Nonetheless, Nueve reinas still represents a major departure from a romantic view of Buenos Aires, as the con men at the centre of the film travel through a space filled with layers of duplicity and criminal activity. This sense of the city as a space pervaded by crime is crystallised in a scene where Marcos warns the seemingly naïve Juan about the extent to which these delinquents are poised to prey on their next victim: 'Están ahí pero no los ves. Bueno

15 'Reading between the lines, it provides some social commentary.'

16 The Sting (Hill, 1973) is a stylish film that also has a labyrinthine plot full of twists. It starred Robert Redford and Paul Newman as a pair of con artists who unite to avenge the death of Redford's partner. 
de eso se trata. Están pero no están. Así que cuida el maletín, la valija, la puerta, la ventana, el auto. Cuida los ahorros. Cuida el culo, porque están ahí y ahí van a estar siempre'. 17

\section{Conclusion}

Taken together, these and other recent Argentine films use mise-en-scène to great effect to comment on the physical and moral degradation of the city. Far from being empty of meaning, these films amount to a damning indictment of a society racked by corruption, fear and economic collapse. Despite their very different tones, aesthetics and subjects, the films discussed above share a sense of disillusionment and even despair with the city in which they are set. The characters who live on the margins in Pizza, birra, faso and Bolivia are trapped in a grindingly monotonous pattern of poverty and frustration that is reflected in their limited movements and repetitive routines. To an extent, this is also the case of Zapa in El bonaerense. The characters in Garage Olimpo are similarly trapped, though in this case by political oppression, although money is also a central theme as Felix's petty theft of the possessions of his torture victims parallels the dictatorship's looting of the country's finances, which in turn paved the way for the disastrous economic situation depicted in Nueve reinas and El hijo de la novia. Although the characters in the last two films ostensibly have more mobility, they too are trapped by the workings of a globalised financial system that they cannot escape.

Taken together, the films form a meta-narrative where the dream of escape features prominently. Diane, in Garage Olimpo, expresses a desire to return to her native France just before she is murdered, while Rafael's girlfriend contemplates a move to Spain. In Pizza, birra, faso, el Cordobés longs to escape to Uruguay, while Freddy misses his home in Bolivia. Martina in Bar 'El Chino' does leave the city, but she is seen to suffer an emotional loss as a result of this decision. What is most notable is the fact that the characters who have the means and the opportunity to leave Buenos Aires tend to stay and confront difficult or even dangerous circumstances by forming or sustaining emotional ties with family or partners. The use of the theme of escape ultimately becomes a metaphor for current filmmaking in the city, as the most fully realised recent films face history and the problems of contemporary society head on, without nostalgia or diversionary tactics. This tendency is most notable in Los rubios, which explicitly foregrounds filmmaking as a possible way of coming to terms with a disturbing history and a complex present. The city is renewed through film as a place where some hope is again possible through a willingness to present uncomfortable truths with honesty, humanity and even, in the case of Más que un hombre, humour.

17 'They're there but you don't see them. Well, that's the whole point. They're there but they're not there. So watch your briefcase, your case, your door, your windows, your car. Watch your savings. Watch your ass, because they are out there and they'll always be there.' 


\section{Reimagining Buenos Aires}

\section{References}

Aguilar, G. (2006) Otros mundos: Un ensayo sobre el nuevo cine argentino. Biblioteca Km 111: Buenos Aires.

Ávila, B. (dir.) (2004) Nietos (identidad y memoria). SBP: Argentina.

Backstein, K. (2004) 'The Blonds'. Cineaste 29(4): 49-50.

Bechis, M. (dir.) (1999) Garage Olimpo. SBP: Argentina.

Bielinsky, F. (dir.) (2000) Nueve reinas. Sony Picture Classics: Argentina.

Braslavsky, G. (2007) 'La inseguridad es el principal reclamo a la gestión de Cristina'. Clarín, 19 November, p. 3.

Brieva, D. and Valina, G. (dirs) (2007) Más que un hombre. Argentina: SBP.

Burak, D. (dir.) (2003) Bar 'El Chino'. Argentina: SBP.

Caetano, A. (dir.) (2001) Bolivia. Argentina: AVH.

Caetano, A. (dir.) (2006) Buenos Aires 1977. Argentina: CINESUR.

Caetano, A. and Stagnaro, B. (dirs) (1997) Pizza, birra, faso. TRANSEUROPA: Argentina.

Campanella, J. J. (dir.) (2001) El hijo de la novia. Sony Picture Classics: Argentina.

Cancela, L. (2004) Mirada de Mosca: Ensayos Sobre Films Argentinos 01/03/... De los Cuatro Vientos Editorial: Buenos Aires.

Carri, A. (dir.) (2003) Los rubios. SBP: Argentina.

Cockrell, E. (2001) 'The Son of the Bride'. Variety 384(4): 66.

Coscia, J. (2005) Del estallido a la esperanza: Reflexiones sobre cine, cultura y Peronismo. Ediciones Corregidor: Buenos Aires.

de Carli, G. (2003) 'Reflections of New Argentine Cinema'. Vertigo 2(4): 38-40.

Díaz, S. (2005) 'La construcción de la marginalidad en el cine argentino: la generación del 60 y el cine de los 90', in A. L. Lusnich (ed.) Civilización y barbarie en el cine argentino y latinoamericano. Biblios: Buenos Aires, 111-123.

Donald, J. (1999) Imagining the Modern City. The Athlone Press: London.

Donoso Pinto, C. (2007) Películas que escuchan: Reconstrucción de la identidad en once filmes chilenos y argentinos. Ediciones Corregidor: Buenos Aires.

Entel, A. (2007) La ciudad y los medios: La pasión restauradora. La Crujía Ediciones: Buenos Aires.

Foster, D. W. (1992) Contemporary Argentine Cinema. University of Missouri Press: Missouri.

Gandsman, A. (2006) 'The Blonds (Los Rubios)'. Journal of Latin American Anthropology 11(1): 253-235.

Gundermann, C. (2005) 'The Stark Gaze of the New Argentine Cinema'. Journal of Latin American Cultural Studies 14(3): 241-261.

Hill, G.R. (dir.) (1973) The Sting. Universal Pictures: USA.

Jacobs, G. (2004) Criminal. Warner Independent Pictures: USA.

Jakubowicz, E. and Radetich, L. (2006) La historia argentina a través del cine: Las 'visiones del pasado’ (1933-2003). La Crujía Ediciones: Buenos Aires.

Jozami, A. (2003) Argentina: La destrucción de una nación. Mondadori: Buenos Aires.

Loose, C. (2005) 'Buenos Aires, Always in Style'. Washington Post, 10 July, pp. 1-5.

Ludin, N. and Milstein, P. (dirs) (2003) Sol de noche. AVH: Argentina.

Maranghello, C. (2005) Breve historia del cine argentino. Laertes: Buenos Aires.

Mazierska, E. and Rascarloi, L. (2003) From Moscow to Madrid: Postmodern Cities, European Cinema. IB Tauris: London.

Mignogna, E. (dir.) (1996) Sol de otoño. AVH: Argentina.

Noriega, G. (2002) 'Freddy toma soda'. Amante Cine 120(14): 14-15.

Nouzeilles, G. (2005) 'Postmemory and the Future of the Past in Albertina Carri's Los rubios'. Journal of Latin American Cultural Studies 14(3): 263-278.

Olivera, H. (dir.) (1986) La noche de los lápices. Marquis Pictures: Argentina. 
Page, J. (2005) 'Memory and Mediation in Los rubios: A Contemporary Perspective on the Argentine Dictatorship'. New Cinemas: Journal of Contemporary Film 3(1): 29-40.

Page, J. (2007) 'Identidades posnacionales y estrategias de reterritorialización en el cine argentine contemporáneo', in M. J. Moore and P. Wolkowicz (eds.) Cines al margen: Nuevos modos de representación en el cine argentine contemporáneo. Libraria: Buenos Aires.

Piñeyro, M. (dir.) (2002) Kamchatka. AVH: Argentina.

Podalsky, L. (1997) 'High-Rise Apartments, Arcades, Cars, and Hoteles de citas: Urban Discourse and the Reconstruction of the Public/Private Divide in 1960s Buenos Aires', in A. M. Stock (ed.) Framing Latin American Cinema: Contemporary Critical Perspectives, University of Minnesota: Minneapolis, 1-26.

Puenzo, L. (dir.) (1985) La historia oficial. Almi Pictures: Argentina.

Quintín, E. A. (1997) 'Ciudad oculta'. Amante Cine (70): 4-6.

Ramsey, C. (1992) 'The Official Story: Feminist Re-Visioning as Spectator Response'. Studies in Latin American Popular Culture 11(157): 169.

Sarlo, B. (1993) 'The Case of Buenos Aires', in J. King, A. M. López and M. Alvarado (eds) Mediating Two Worlds: Cinematic Encounters in the Americas. British Film Institute: London, 164-175.

Smith, P. J. (2004) 'Where Everything's For Sale'. Sight and Sound (5): 11.

Suárez, P. (2003) 'Amidst Political Chaos, Social Instability, and Economic Meltdown, the New Argentine Cinema Continues to Bear Witness'. Film Comment 39(5): 11-15.

Trapero, P. (dir.) (2002) El bonaerense. Argentina: AVH.

Triquell, X. (1997) 'Del cine-testimonio al cine-testamento: El cine político argentino de los 1980 a los 1990', in R. Rix and R. Rodriguez-Saona (eds) Latin American Cinema Against the Odds. Leeds Iberian Papers: Leeds, 59-74.

Vidal, E. (1999) 'Pizza, Bizza, Faso', in M. Satarain (ed.) Plano secuencia: 20 películas argentinas para reafirmar la democracia. La Crujía Ediciones: Buenos Aires, 159-164.

Walters, B. (2003) 'El Bonaerense'. Sight and Sound (11): 33-34.

West, D. (2001) 'The Buenos Aires Film Festival and the Renaissance of Argentine Cinema'. Cineaste 27(1): 50-51. 
Copyright of Bulletin of Latin American Research is the property of Blackwell Publishing Limited and its content may not be copied or emailed to multiple sites or posted to a listserv without the copyright holder's express written permission. However, users may print, download, or email articles for individual use. 